\title{
Ontogeny of Bradykinin B1 Receptors in the Mouse Kidney
}

\author{
OZLEM PINAR BULUT, SUSANA DIPP, AND SAMIR EL-DAHR
}

\author{
Department of Pediatrics, Tulane University Health Sciences Center, New Orleans, Louisiana 70112
}

\begin{abstract}
Kinins are vasoactive peptides that stimulate two G-protein coupled bradykinin receptors (B1R and B2R). B2Rknockout mice are salt sensitive and develop renal dysgenesis and hypertension if salt stressed during embryogenesis. B1R-knockout mice, on the other hand, are protected from inflammation and fibrosis. This study examined the spatiotemporal expression of B1R during renal organogenesis. The segmental nephron identity of B1R immunoreactivity was determined by costaining with markers of the collecting duct (Dolichos biflorus), proximal tubule (Dolichos tetraglonus), and nephron progenitors (Pax2). At E14.5, the B1R was confined to few cells in the metanephric mesenchyme. Abundance of $\mathrm{B} 1 \mathrm{R}$ increased progressively during development. On E17.5, B1R was enriched in differentiating proximal tubular cells and by postnatal day 1, B1R was clearly expressed on the luminal aspect of the proximal tubule. Quantitative real-time PCR revealed that the levels of B1R mRNA more than double during renal maturation. We conclude that 1) B1R expression correlates closely with nephron maturation; 2) lack of $\mathrm{B} 1 \mathrm{R}$ in nephron progenitors suggests that $\mathrm{B} 1 \mathrm{R}$ is unlikely to play a role in early nephrogenesis; and 3) enrichment of $\mathrm{B} 1 \mathrm{R}$ in maturing proximal tubule suggests a potential role for this receptor in terminal differentiation of the proximal nephron. (Pediatr
\end{abstract} Res 66: 519-523, 2009)

$\mathrm{K}$ inins, including bradykinin (BK), are formed from partial hydrolysis of kininogen by a family of serine proteases called kallikreins. Kinins produce their effects by binding and activation of two types of receptors, B1R and B2R (reviewed in Ref. 1). Activation of the B2R by BK stimulates nitric oxide and prostaglandin production and results in vasodilation and natriuresis (2). Hence, mice lacking the $\mathrm{B} 2 \mathrm{R}$ gene have the propensity to develop salt-sensitive hypertension (3-5). Accumulating evidence also indicates that $\mathrm{B} 2 \mathrm{R}$ plays important developmental functions in the kidney and elsewhere under embryonic stress conditions (6-8).

The B1R is activated by Des-Arg ${ }^{9}-\mathrm{BK}$, a natural product of $\mathrm{BK}$ produced by the carboxypeptidase, kininase I. B1R are induced by tissue injury and are believed to mediate inflammatory responses (9-14). Several transcription factors are known to regulate the B1R and B2R genes including NF- $\kappa \mathrm{B}$ and p53 (15-17). In this regard, p53 was reported to repress B1R but to activate B2R gene transcription (18-21). Indeed,

Received April 28, 2009; accepted June 24, 2009

Correspondence: Samir S. El-Dahr, M.D., Department of Pediatrics, SL-37, Tulane University School of Medicine, 1430 Tulane Avenue, New Orleans, LA 70112; e-mail: seldahr@tulane.edu

Supported by NIH grants DK-56264 and DK-62250 and the Tulane Renal and Hypertension Center of Excellence.

O.P.B. is a PL-3 resident in Pediatrics, Tulane University School of Medicine.

He performed this work during a laboratory research rotation as part of pediatric residency requirement at Tulane University School of Medicine. kidney p53 levels decrease dramatically during development $(22,23)$, which may account for the maturational decline in B2R gene expression (24). Because p53 represses the B1R promoter (21), it is anticipated that B1R expression is upregulated as p53 levels decline during development. To our knowledge, the developmental expression of B1R is unknown. Accordingly, this study was designed to determine the ontogeny of B1R and map the localization of this receptor in the developing nephron.

\section{METHODS}

The study was approved by Tulane University School of Medicine Animal Care and Use Committee.

Immunostaining. Embryos from timed-pregnant CD1 mice (Charles Rivers Laboratories) were harvested on embryonic days E14.5, E17.5, and postnatal days $\mathrm{P} 1, \mathrm{P} 10, \mathrm{P} 20$, and $\mathrm{P} 90$ ( $n=4-6$ per age group). Immunostaining procedures were performed as described previously $(6,25,26)$. Kidneys were fixed in $10 \%$ buffered formalin, dehydrated in graded solutions of alcohol, and embedded in paraffin blocks, and 5- $\mu \mathrm{m}$ sections were cut and mounted on Vectabond-coated slides (Vector Laboratories, Burlingame, CA). Antigen retrieval was performed by immersing slides in $10-\mathrm{mM}$ citric acid and boiling in a microwave for $20 \mathrm{~min}$. Immunostaining was performed using the immunoperoxidase technique with a Vectastain Elite kit (Vector Laboratories). The sections were dewaxed in xylene, rehydrated, and treated with absolute methanol and $1 \% \mathrm{H}_{2} \mathrm{O}_{2}$ for 30 min to block endogenous peroxidase activity. Subsequently, tissue sections were sequentially incubated at room temperature with 1) normal serum for $20 \mathrm{~min}$ for blocking; 2) primary antibody, a polyclonal antibody raised in goat directed against an N-terminus epitope of mouse BK B1R (sc-15045, A-16) (Santa Cruz Biotechnology) diluted from $1 / 50$ to $1 / 500 ; 3$ ) secondary antibody, biotin-conjugated horse anti-goat $\mathrm{IgG}$ for $30 \mathrm{~min}$; and 4) avidin $\mathrm{DH}$, biotinylated horseradish peroxidase $\mathrm{H}$ complex for $45 \mathrm{~min}$. Peroxidase activity was visualized with $0.01 \%$ $3,3^{\prime}$-diaminobenzidine tetrahydrochloride (polysciences) in the presence of $0.02 \% \mathrm{H}_{2} \mathrm{O}_{2}$ as a source of peroxidase substrate for $4-8 \mathrm{~min}$. Lectins tetraglobus (LTA) and Dolichos biflorus (DBA) were used to label the proximal tubules and collecting ducts, respectively, and a polyclonal rabbit Pax2 antibody (Zymed) was used to label the nephrogenic zone. Slides were photographed using an Olympus model SC 35 camera mounted to an Olympus model BH-2 microscope, and digital images were captured using Adobe Photoshop software.

Specificity of immunostaining. The specificity of immunostaining was determined by 1 ) preadsorption of the antibody with the amino acid peptide of the B1 receptor protein used to generate the antibody, 2) omission of the primary antibody, and 3) omission of the secondary antibody. For the preadsorption studies, the synthetic peptide (seven dilutions spanning 6 $\mu \mathrm{M}-260 \mathrm{mM}$ ) was incubated with the antibody overnight at $4^{\circ} \mathrm{C}$ centrifuged at $10,000 \times \mathrm{g}$ for $10 \mathrm{~min}$ at $4^{\circ} \mathrm{C}$ and then added directly to the tissue section (total volume $45 \mu \mathrm{L}$ ).

Section immunofluorescence. After the slides were deparaffinized in xylene followed by an ethanol series rehydration, they were washed in PBS twice before antigen retrieval was performed as described earlier. The sections were again washed twice for $10 \mathrm{~min}$ each before blocking with $10 \%$ serum in $0.1 \%$ BSA in PBS for $30 \mathrm{~min}$ in a humidity chamber. The primary antibody was diluted in 3\% BSA in PBS and added to the sections overnight in a humidity chamber at $4^{\circ} \mathrm{C}$. Primary antibodies included a goat anti-mouse

Abbreviations: B1R, bradykinin B1 receptor; B2R, bradykinin B2 receptor; BK, bradykinin 
B1R (described earlier) and in some sections, neural cell adhesion molecule (N-CAM; mouse monoclonal, 1:300; Sigma Chemical Co.). The slides were then washed in PBST (PBS with $0.1 \%$ Tween) three times for 10 min each before incubation with secondary antibody in PBS in a humidity chamber at room temperature in the dark for $1 \mathrm{~h}$. Secondary antibody was rabbit anti-goat Alexa Fluor $594(1: 3,000)$. FITC-labeled LTA was used to mark proximal tubules (molecular probes). The sections were again washed three times for 10 min each in PBST followed by a final wash in PBS before being mounted with Dako antifade fluorescent mounting medium under glass coverslips.

Quantitative real-time $R$ T-PCR. Total kidney RNA was extracted using Trizol (Invitrogen) from three to five animals in each group. RNA (20 ng per reaction) was reverse transcribed, and real-time PCR was performed in quadruplicate using the Applied Biosystems 7500 Fast Real-time PCR system and TaqMan GenExpression Assays (Applied Biosystems) for mouse BdkrB1 (assay ID Mm00432059s1) and gapdh (endogenous control, FAM/MGB probe, nonprimer limited; no. 4352932E). The setup of reaction consisted of $1 \mu \mathrm{L}$ of cDNA (100 ng), $1 \mu \mathrm{L}$ of TaqMan primer set, $10 \mu \mathrm{L} \mathrm{Taq}$ [TaqMan Fast Universal PCR master mix (2×), No AmpErase UNG; no. 4366072], and $8 \mu \mathrm{L}$ of $\mathrm{H}_{2} \mathrm{O}$ under the following PCR conditions: step $1,95^{\circ} \mathrm{C}$ for $20 \mathrm{~s}$ (enzyme activation); step $2,95^{\circ} \mathrm{C}$ for $3 \mathrm{~s}$ (melting); and step $3,60^{\circ} \mathrm{C}$ for $30 \mathrm{~s}$ (annealing and extension); steps 2 and 3 were repeated 40 times.

\section{RESULTS}

Histologic analysis of nephrogenesis. Figure $1 A-C$ depicts the stages of nephrogenesis. After induction by the ureteric bud, the metanephric mesenchyme undergoes mesenchymeto-epithelium conversion leading to successive stages of nephrons in a centrifugal manner. The periphery of the developing kidney contains the most immature nephrons, i.e. nephron progenitors, consisting of the vesicle, comma-shaped, $\mathrm{S}$-shaped, and maturing glomeruli/nephrons. The first three stages can be labeled by neural cell adhesion molecule (N-CAM) marking the nephrogenic zone (Fig. 1A). The maturing nephrons are situated in the deep cortex and can be
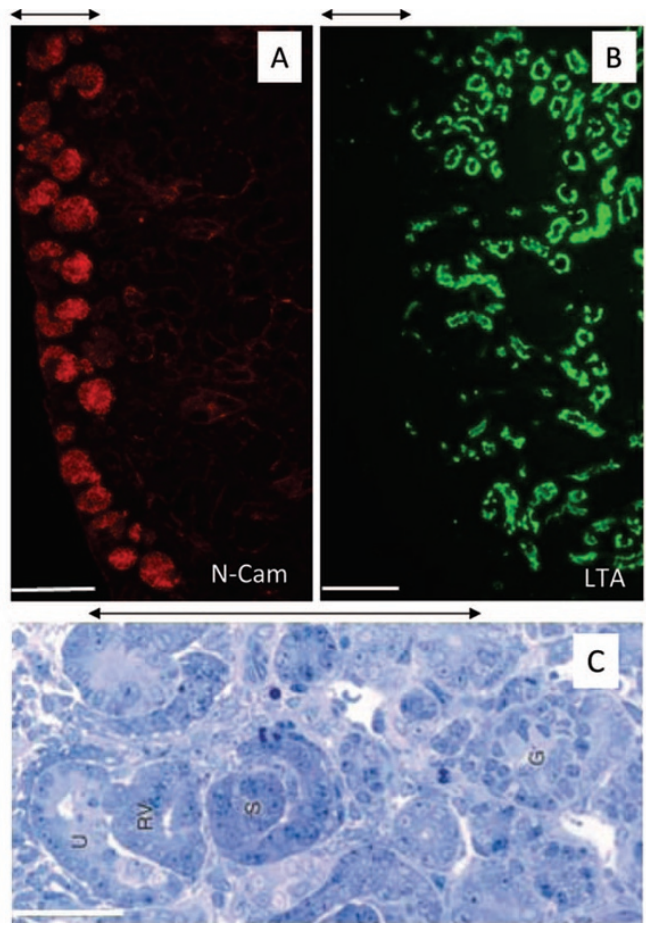

Figure 1. Kidney tissue section from P1 newborn mouse. Immunofluorescence for $(A) \mathrm{N}-\mathrm{Cam}$ and $(B)$ LTA to delineate the nephrogenic and differentiation zones, respectively (magnification $\times 20$ ). $C$, Hematoxylin-stained section showing the various stages of nephrogenesis. $U$, ureteric bud tip; $\mathrm{RV}$, renal vesicle; $\mathrm{S}$, S-shaped body; G, maturing glomerulus. Magnification $\times 60$.
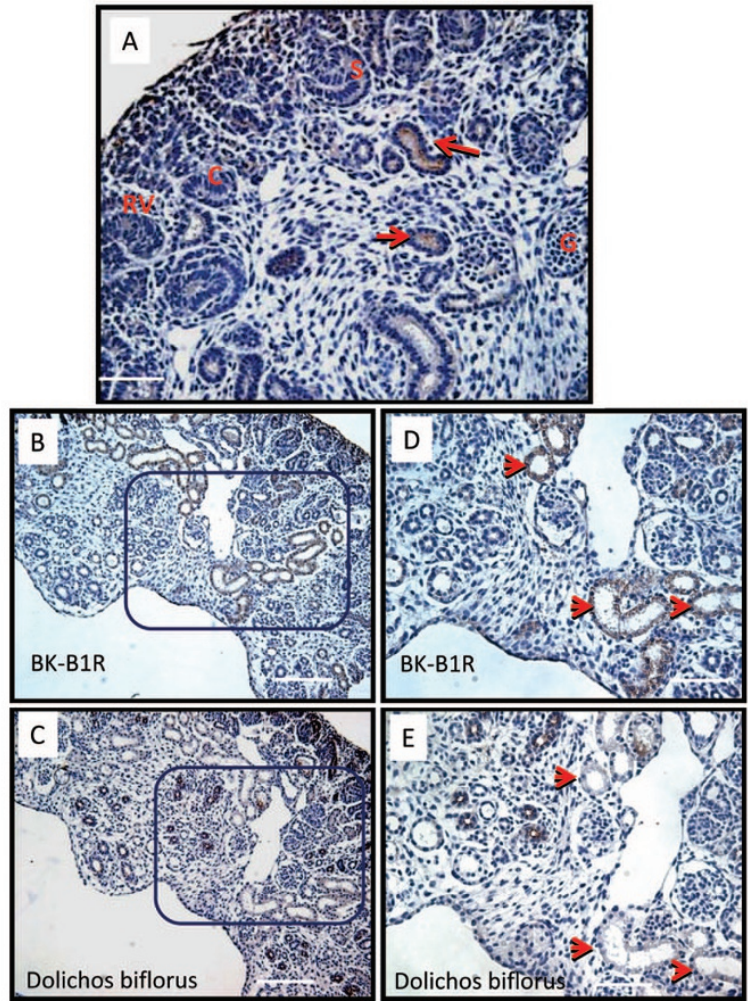

Figure 2. $A$, Tissue section showing B1R immunostaining in E14.5 mouse embryonic kidney (magnification $\times 40$ ). Arrows point to positively stained maturing tubules. Note that nephron precursors, which include renal vesicles (RV), comma- and S-shaped bodies $(\mathrm{C}, \mathrm{S})$ are B1R negative. Low $(\times 20)$ and high $(\times 40)$ power views of tissue sections stained for B1R $(B, D)$ or DBA $(C$, $E)$ in E17.5 mouse kidney. B1R immunoreactivity is present in the deep cortex in a nonoverlapping manner with DBA, indicating that B1R-nephron segments are derived from the proximal nephron.

labeled by a marker of the proximal tubules (e.g. LTA) (Fig. $1 B)$. The various stages of nephron maturation are depicted in a histologic section (Fig. 1C).

Immunolocalization of the B1R. Histologic analysis of the mouse kidney at E14.5 reveals the presence of the four major stages of nephrogenesis: renal vesicle (RV), comma-shaped (C), S-shaped (S), and maturing glomeruli (G) (Fig. 2A). Immunolabeling with the $\mathrm{B} 1 \mathrm{R}$ antibody was performed using various concentrations ranging from $1 / 50$ to $1 / 500$. B1R immunoreactivity was low at this developmental stage and was only detectable at relatively higher concentrations of B1R antibody (1/50-1/100) (Fig. 2A). The nephrogenic zone contained few B1R-positive cells. On the other hand, tubules located in the deep cortex and associated with maturing glomeruli expressed detectable levels of B1R. In these tubules, B1R was observed predominantly on the apical aspect of the tubular cells (Fig. 2A, arrows). To determine the origin of these tubules, we stained consecutive sections of E14.5 kidneys with B1R and DBA lectin, a marker of the collecting ducts. DBA-stained epithelia were B1R negative (data not shown). Similarly, glomeruli did not contain B1R immunoreactivity. These findings suggested that B1R-positive tubules are derived from the proximal nephron.

By E17.5, the cortex has demarcated into a well-formed nephrogenic zone and a differentiation zone containing ma- 
turing nephrons. The medulla also contains round tubules consisting of the loops of Henle and collecting ducts. Fig. $2 B$ and $D$ show lower power views of consecutive sections stained for B1R and DBA, respectively. B1R immunoreactivity was observed in elongated and curved tubules in the deep cortex, whereas DBA staining was seen mainly in round tubular sections located in the medulla (medullary-collecting ducts) and straight tubules in the periphery (cortical-collecting ducts). At higher power views, B1R immunoreactivity and DBA are expressed in a nonoverlapping manner (arrows in Fig. $2 D$ and $E$ ). These findings are consistent with the conclusion that B1R are not expressed in the collecting ducts. Of note, B1R immunoreactivity was not detectable in glomeruli or renal microvessels.

To further delineate the regional expression of B1R in the developing kidney, we compared the expression pattern of $\mathrm{B} 1 \mathrm{R}$ and Pax2. Pax2 is a transcription factor, which plays a key role in renal development (27) and is expressed in epithelial nephron progenitors and UB branches. This pattern of expression is seen in Fig. $3 A$. In comparison, B1R is expressed in more differentiated tubules in the deep cortex (Fig. 3B). Thus, Pax2 and B1R mark different stages of nephron maturation, the nephron progenitors, and differentiated proximal tubules, respectively.

After birth, on postnatal day 1, B1R immunoreactivity increased in abundance and was clearly detected in the proximal tubules (Fig. 4A and $B$ ). Within the proximal tubule, B1R was diffusely expressed in a basolateral distribution and apically. Glomeruli and medullary rays (loop of Henle, vasa recta, and collecting ducts) were B1R negative. To confirm the precise segmental localization of B1R, we performed double immunofluorescence for B1R and LTA (a proximal tubule maker) on tissue sections from P1 kidneys. B1R (red) was expressed in both basolateral and apical aspects of LTApositive tubules (green) (Fig. 4C). LTA-negative tubules were also devoid of B1R immunoreactivity. These results confirm that the major site of B1R expression in the developing kidney is the proximal tubule.

Specificity of immunostaining. To determine the specificity of B1R immunostaining, we performed the following control experiments. First, we preadsorbed the primary antibody with increasing concentrations of the $\mathrm{B} 1 \mathrm{R}$ antigenic peptide $(\times 5$ to 50 -fold). After incubation overnight at $4{ }^{\circ} \mathrm{C}$ and centrifugation of the antigen-antibody complexes, the sections were
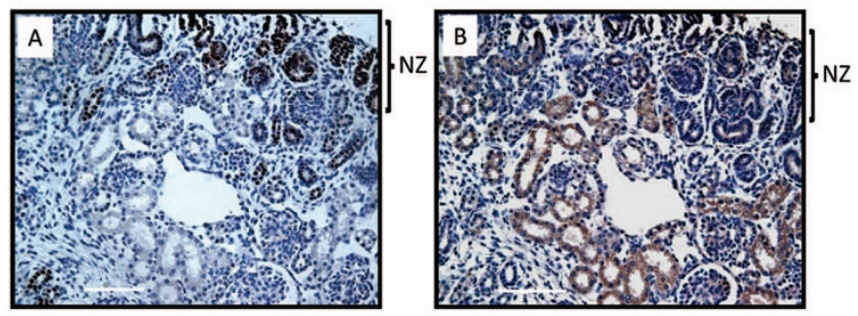

Figure 3. Consecutive sections from a P1 mouse kidney immunostained for Pax2 $(A)$ and B1R (B). Pax2 marks the nephrogenic zone (NZ). B1Rexpressing tubules are located in the deep more mature cortical region. Magnification $\times 40$.

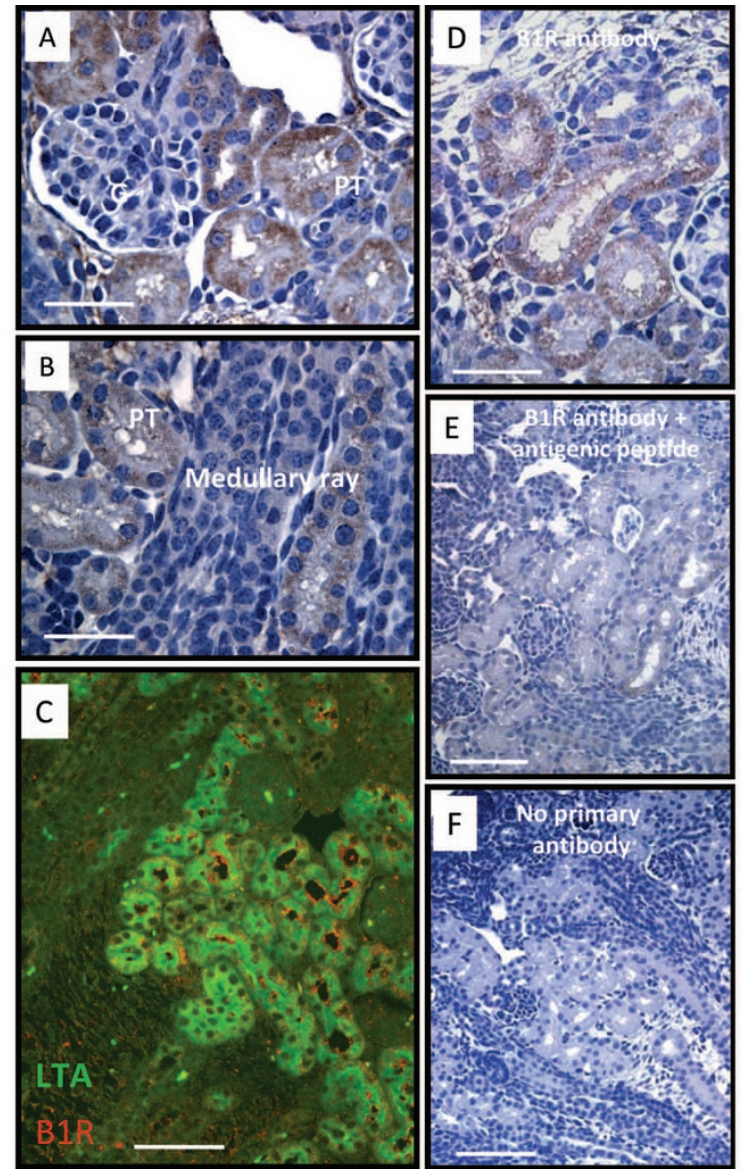

Figure 4. B1R immunostaining in $\mathrm{P} 1$ kidney tissue section. $A, \mathrm{~B} 1 \mathrm{R}$ immunostaining is present in proximal tubules but is absent from glomeruli and medullary rays $(B)$. Magnification $\times 60$. $C$, Double immunofluorescence for $\mathrm{B} 1 \mathrm{R}$ (red) and LTA (green) in a P1 kidney tissue section (magnification $\times 40$ ). B1R immunoreactivity is present in proximal tubules on both luminal and basolateral aspects. $D-F$, Immunostaining specificity controls. $D, \mathrm{~B} 1 \mathrm{R}$ immunostaining in P1 kidney tissue section showing the expected localization in the proximal tubules $(\times 60)$. $E$, Preadsorbption of the primary antibody with $\times 25$ antigen excess eliminates the staining $(\times 40) . F$, Omission of the primary antibody also eliminates specific immunoreactivity $(\times 40)$.

incubated with the supernatant. The results revealed that specific B1R immunoreactivity was greatly attenuated by as little as 5-fold excess of antigenic peptide and was completely abolished by incubation with 25 -fold or higher concentrations (Fig. 5A and $B$ ). Second, we eliminated the primary or secondary antibodies steps during the immunostaining procedure; this resulted in a low background or no staining (Fig. 5C). Collectively, these results demonstrate the specificity of the B1R antibody used in this study.

Developmental changes of B1R gene expression in the kidney. Our immunohistochemical results have shown that the $\mathrm{B} 1 \mathrm{R}$ protein is expressed at relatively low levels in E14.5 metanephroi followed by a gradual rise in abundance with maturation. To provide a more quantitative assessment of B1R gene expression, we performed real-time quantitative RT-PCR on RNA isolated from embryonic (E14.5 and E17.5) and postnatal (P1, P10, P20, and P90) kidneys (Fig. 5). B1R mRNA levels were factored for the housekeeping gene, $\beta$-actin, and presented as percent of adult levels. The results demonstrated 


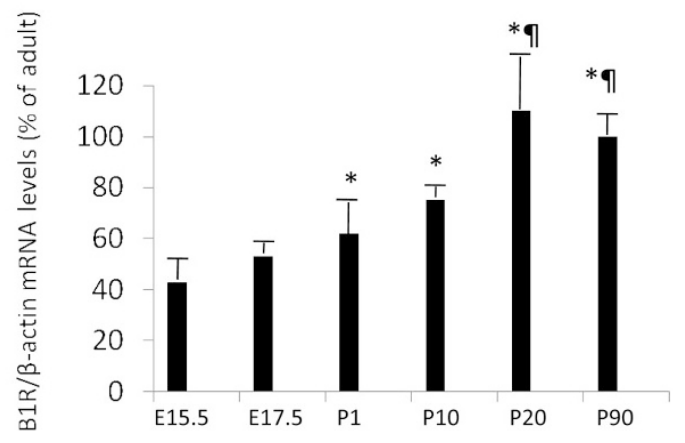

Figure 5. Quantitative real-time RT-PCR of B1R mRNA in mouse kidneys of different developmental stages. ${ }^{*} p<0.05$ vs E15.5; I $p<0.05$ vs P1 $(n=3$ in triplicates).

that metanephric B1R transcript levels double in amounts from E15.5 to P20, when adult expression levels are attained.

\section{DISCUSSION}

Previous studies have demonstrated that the developing kidney expresses a local kallikrein-kinin system (KKS), including kallikrein, kininogen, and BK B2 receptors (28-32). Tissue kallikrein is produced by the connecting tubule $(33,34)$. After release, kallikrein cleaves low-molecular weight kininogen, which is synthesized in the collecting duct (34), to release the nonapetide BK. Kininase I, a carboxypetidase, cleaves the terminal arginine of BK to form Des-Arg ${ }^{9}$-BK. Although BK preferentially stimulates the B2 receptor, Des-Arg ${ }^{9}$-BK stimulates the $\mathrm{B} 1$ receptor. $\mathrm{B} 1 \mathrm{R}$ and $\mathrm{B} 2 \mathrm{R}$ belong to the seven transmembrane G-protein coupled receptor family, and share several signal transduction pathways, such as activation of intracellular calcium and protein kinase $\mathrm{C}$, and downstream transcription factors NF- $\kappa \mathrm{B}$ and AP-1 $(35,36)$. However, the two receptors differ in many other respects, e.g. B1R is resistant to receptor desensitization and is an inducible receptor. Moreover, although B1R and B2R genes are regulated by common transcription factors such as NF- $\kappa \mathrm{B}, \mathrm{AP}-1$, and CREB, the two gene promoters respond in an opposite manner to $\mathrm{p} 53$ $(18,21,37)$. Gene disruption strategies in mice have shown that B1R is up-regulated in B2R-null mice $(38,39)$ and plays a role in compensating for $\mathrm{B} 2 \mathrm{R}$ in the regulation of cardiovascular protection. Indeed, double B1R/B2R-knockout mice are extremely vulnerable to oxidative stress, DNA damage, and senescence and are at high risk for developing diabetes (40-42).

Although previous studies have carefully characterized the developmental expression of the B2R in the kidney, there is little if any information regarding the ontogeny of B1R. Studies performed in our laboratory and by others have demonstrated that the abundance of B2R mRNA is 10- to 30-fold higher in neonatal than adult tissues $(24,43)$. Receptor autoradiography further indicates that most kinin receptors in the developing kidney belong to the B2 type (24). Immunolocalization studies revealed that $\mathrm{B} 2 \mathrm{R}$ are first expressed on the luminal aspect of the upper limb of S-shaped bodies and differentiating cortical collecting ducts. In marked contrast, the metanephric mesenchyme, pretubular aggregates, proximal tubules, and glomeruli display weak or no B2 receptor immunoreactivity (24). After completion of nephrogenesis, B2 receptor expression shifts to both luminal and basolateral aspects of connecting tubules and collecting ducts $(43,44)$.

This study provides new information regarding the developmental expression of the KKS in the mouse kidney. We found that B1R gene expression (mRNA) is low during fetal life and is up-regulated postnatally, and that maturing proximal tubules are the predominant sites expressing B1R protein in the developing nephron. Given these and other results, it is worth considering the differences in the developmental expression of B1R and B2R. First, B2R is constitutively expressed during development and decreases after the end of nephrogenesis $(24,31,43)$. In comparison, B1R is expressed at low levels before birth, after which time B1R increases progressively reaching adult levels by the time of weaning. Second, B2R is enriched in the ureteric bud branches, the precursors of the collecting ducts $(43,45)$; there is also modest amount of B2R in the developing glomerulus (rat) (43). B1R, on the other hand, is not expressed in glomeruli or collecting ducts and is almost exclusively expressed in the proximal tubules. However, this does not rule the possibility that B1R might be induced along new nephron sites in response to stress.

The potential functions of B1R in the developing kidney are unknown. It would be important to know first whether the B1R ligand, Des-Arg' ${ }^{9}$-BK, is produced by the developing kidney. This will require some knowledge of the ontogeny of kininase I, which generates Des-Arg 9 -Bk from BK. B1Rknockout mice are viable but exhibit immune and inflammatory dysfunctions $(46,47)$, but to our knowledge, a formal evaluation of nephrogenesis or differentiation has not been reported. B2R on the other hand, has clear developmental functions that include modulation of renal blood flow through antagonism of angiotensin II (48), protection against early onset of salt-sensitive hypertension (49), and fetal nephroprotection in response to gestational salt stress $(6,50)$. Whether $\mathrm{B} 1 \mathrm{R}$ exerts physiologic actions on the structural or functional maturation of the proximal tubule remains to be determined. In this regard, the maturational up-regulation of B1R parallels that of AQP-1, a water channel and a marker of the differentiated proximal tubule (51). A recent study reported that stimulation of $\mathrm{B} 1 \mathrm{R}$ on keratinocytes triggers tyrosine kinase signaling and transactivation of the epidermal growth factor receptor (52). Interestingly, B1R-epidermal growth factor receptor cross talk was associated with cellular differentiation rather than proliferation, as assessed by expression of terminal differentiation epidermal markers (52). Future studies aimed at delineating the renal structural, biochemical, and functional phenotypes in B1R-knockout mice are necessary to determine the precise role of $\mathrm{B} 1 \mathrm{R}$ in the kidney.

\section{REFERENCES}

1. Madeddu P, Emanueli C, El-Dahr S 2007 Mechanisms of disease: the tissue kallikrein-kinin system in hypertension and vascular remodeling. Nat Clin Pract Nephrol 3:208-221

2. Siragy HM, Jaffa AA, Margolius HS 1997 Bradykinin B2 receptor modulates renal prostaglandin E2 and nitric oxide. Hypertension 29:757-762

3. Alfie ME, Sigmon DH, Pomposiello SI, Carretero OA 1997 Effect of high salt intake in mutant mice lacking bradykinin-B2 receptors. Hypertension 29:483-487

4. Cervenka L, Maly J, Karasova L, Simova M, Vitko S, Hellerova S, Heller J, El-Dahr SS 2001 Angiotensin II-induced hypertension in bradykinin B2 receptor knockout mice. Hypertension 37:967-973 
5. Madeddu P, Emanueli C, Gaspa L, Salis B, Milia AF, Chao L, Chao J 1999 Role of the bradykinin B2 receptor in the maturation of blood pressure phenotype: lesson from transgenic and knockout mice. Immunopharmacology 44:9-13

6. El-Dahr SS, Aboudehen K, Dipp S 2008 Bradykinin B2 receptor null mice harboring a Ser23-to-Ala substitution in the p53 gene are protected from renal dysgenesis. Am J Physiol Renal Physiol 295:F1404-F1413

7. Emanueli C, Madeddu P 1999 Role of the kallikrein-kinin system in the maturation of cardiovascular phenotype. Am J Hypertens 12:988-999

8. Schanstra JP, Duchene J, Praddaude F, Bruneval P, Tack I, Chevalier J, Girolami JP, Bascands JL 2003 Decreased renal NO excretion and reduced glomerular tuft area in mice lacking the bradykinin B2 receptor. Am J Physiol Heart Circ Physiol 284:H1904-H1908

9. Leeb-Lundberg LM, Marceau F, Muller-Esterl W, Pettibone DJ, Zuraw BL 2005 International union of pharmacology. XLV. Classification of the kinin recepto family: from molecular mechanisms to pathophysiological consequences. Pharmacol Rev 57:27-77

10. Marin-Castano ME, Schanstra JP, Praddaude F, Pesquero JB, Ader JL, Girolami JP, Bascands JL 1998 Differential induction of functional B1-bradykinin receptors along the rat nephron in endotoxin induced inflammation. Kidney Int 54:1888-1898

11. Schanstra JP, Bachvarova M, Neau E, Bascands JL, Bachvarov D 2007 Gene expression profiling in the remnant kidney model of wild type and kinin B1 and B2 receptor knockout mice. Kidney Int 72:442-454

12. Schanstra JP, Marin-Castano ME, Praddaude F, Tack I, Ader JL, Girolami JP, Bascands JL, Jeunier B 2000 Bradykinin B(1) receptor-mediated changes in renal hemodynamics during endotoxin-induced inflammation. J Am Soc Nephrol $11: 1208-1215$

13. Marceau F, Larrivee JF, Saint-Jacques E, Bachvarov DR 1997 The kinin B receptor: an inducible G protein coupled receptor. Can J Physiol Pharmacol 75:725730

14. Marceau F, Hess JF, Bachvarov DR 1998 The B1 receptors for kinins. Pharmacol Rev 50:357-386

15. Baptista HA, Avellar MC, Araujo RC, Pesquero JL, Schanstra JP, Bascands JL, Esteve JP, Paiva AC, Bader M, Pesquero JB 2002 Transcriptional regulation of the rat bradykinin B2 receptor gene: identification of a silencer element. Mol Pharmacol 62:1344-1355

16. Ni A, Chao L, Chao J 1998 Transcription factor nuclear factor kappaB regulates the inducible expression of the human B1 receptor gene in inflammation. $\mathrm{J}$ Biol Chem 273:2784-2791

17. Yang X, Taylor L, Polgar P 1998 Mechanisms in the transcriptional regulation of bradykinin B1 receptor gene expression. Identification of a minimum cell-type specific enhancer. J Biol Chem 273:10763-10770

18. Saifudeen Z, Du H, Dipp S, El-Dahr SS 2000 The bradykinin type 2 receptor is a target for p53-mediated transcriptional activation. J Biol Chem 275:15557-15562

19. Merino VF, Silva JA Jr, Araujo RC, Avellar MC, Bascands JL, Schanstra JP, Paiva AC, Bader M, Pesquero JB 2005 Molecular structure and transcriptional regulation by nuclear factor-kappaB of the mouse kinin B1 receptor gene. Biol Chem 386:515522

20. Angers M, Drouin R, Bachvarova M, Paradis I, Bissell B, Hiromura M, Usheva A, Bachvarov D 2005 In vivo DNase I-mediated footprinting analysis along the human bradykinin B1 receptor (BDKRB1) gene promoter: evidence for cell-specific regulation. Biochem J 389:37-46

21. Yang X, Taylor L, Polgar P 2001 p53 down-regulates human bradykinin B1 receptor gene expression. J Cell Biochem 82:38-45

22. Saifudeen Z, Diavolitsis V, Stefkova J, Dipp S, Fan H, El-Dahr SS 2005 Spatiotemporal switch from DeltaNp73 to TAp73 isoforms during nephrogenesis: impact on differentiation gene expression. J Biol Chem 280:23094-23102

23. Saifudeen Z, Dipp S, El-Dahr SS 2002 A role for p53 in terminal epithelial cell differentiation. J Clin Invest 109:1021-1030

24. El-Dahr SS, Figueroa CD, Gonzalez CB, Muller-Esterl W 1997 Ontogeny of bradykinin B2 receptors in the rat kidney: implications for segmental nephron maturation. Kidney Int 51:739-749

25. Fan H, Stefkova J, El-Dahr SS 2006 Susceptibility to Metanephric apoptosis in bradykinin B2 receptor null mice via the p53-bax pathway. Am J Physiol Renal Physiol 291:F670-F682

26. Harrison-Bernard LM, Navar LG, Ho MM, Vinson GP, El-Dahr SS 1997 Immunohistochemical localization of ANG II AT1 receptor in adult rat kidney using a monoclonal antibody. Am J Physiol 273:F170-F177

27. Torres M, Gomez-Pardo E, Dressler GR, Gruss P 1995 Pax-2 controls multiple steps of urogenital development. Development 121:4057-4065

28. Velarde V, Humphreys J, Figueroa CD, Vio CP 1995 Postnatal maturation of tissue kallikrein-producing cells (connecting tubule cells) in the rat kidney: a morphometric and immunohistochemical study. Anat Embryol (Berl) 192:407-414
29. Bascands JL, Marin Castano ME, Bompart G, Pecher C, Gaucher M, Girolami JP 1996 Postnatal maturation of the kallikrein-kinin system in the rat kidney: from enzyme activity to receptor gene expression. J Am Soc Nephrol 7:81-89

30. el-Dahr SS 1997 Ontogeny of the intrarenal kallikrein-kinin system: proposed role in renal development. Microsc Res Tech 39:222-232

31. El-Dahr SS 2004 Spatial expression of the kallikrein-kinin system during nephrogenesis. Histol Histopathol 19:1301-1310

32. Schmaier AH 2003 The kallikrein-kinin and the renin-angiotensin systems have a multilayered interaction. Am J Physiol Regul Integr Comp Physiol 285:R1-R13

33. Figueroa CD, MacIver AG, Mackenzie JC, Bhoola KD 1988 Localisation of immunoreactive kininogen and tissue kallikrein in the human nephron. Histochemistry 89:437-442

34. Hermann A, Braun A, Figueroa CD, Muller-Esterl W, Fritz H, Rehbock J 1996 Expression and cellular localization of kininogens in the human kidney. Kidney In 50:79-84

35. Campbell DJ 2001 The kallikrein-kinin system in humans. Clin Exp Pharmaco Physiol 28:1060-1065

36. Katori M, Majima M 2003 The renal kallikrein-kinin system: its role as a safety valve for excess sodium intake, and its attenuation as a possible etiologic factor in salt-sensitive hypertension. Crit Rev Clin Lab Sci 40:43-115

37. Marks J, Saifudeen Z, Dipp S, El-Dahr SS 2003 Two functionally divergent p53-responsive elements in the rat bradykinin B2 receptor promoter. J Biol Chem 278:34158-34166

38. Duka A, Kintsurashvili E, Duka I, Ona D, Hopkins TA, Bader M, Gavras I, Gavras H 2008 Angiotensin-converting enzyme inhibition after experimental myocardial infarct: role of the kinin B1 and B2 receptors. Hypertension 51:1352-1357

39. Duka I, Kintsurashvili E, Gavras I, Johns C, Bresnahan M, Gavras H 2001 Vasoactive potential of the $\mathrm{b}(1)$ bradykinin receptor in normotension and hypertension. Circ Res 88:275-281

40. Kakoki M, Kizer CM, Yi X, Takahashi N, Kim HS, Bagnell CR, Edgell CJ, Maeda N, Jennette JC, Smithies O 2006 Senescence-associated phenotypes in Akita diabetic mice are enhanced by absence of bradykinin B2 receptors. J Clin Invest 116:13021309

41. Kakoki M, McGarrah RW, Kim HS, Smithies O 2007 Bradykinin B1 and B2 receptors both have protective roles in renal ischemia/reperfusion injury. Proc Natl Acad Sci USA 104:7576-7581

42. Kakoki M, Takahashi N, Jennette JC, Smithies O 2004 Diabetic nephropathy is markedly enhanced in mice lacking the bradykinin B2 receptor. Proc Natl Acad Sci USA 101:13302-13305

43. El-Dahr SS, Dipp S, Meleg-Smith S, Pinna-Parpaglia P, Madeddu P 2000 Fetal ontogeny and role of metanephric bradykinin B2 receptors. Pediatr Nephrol 14:288 296

44. Saifudeen Z, Dipp S, Fan H, El-Dahr SS 2005 Combinatorial control of the bradykinin B2 receptor promoter by p53, CREB, KLF-4, and CBP: implications for terminal nephron differentiation. Am J Physiol Renal Physiol 288:F899-F909

45. El-Dahr SS, Harrison-Bernard LM, Dipp S, Yosipiv IV, Meleg-Smith S 2000 Bradykinin B2 null mice are prone to renal dysplasia: gene-environment interactions in kidney development. Physiol Genomics 3:121-131

46. Cayla C, Todiras M, Iliescu R, Saul VV, Gross V, Pilz B, Chai G, Merino VF Pesquero JB, Baltatu OC, Bader M 2007 Mice deficient for both kinin receptors are normotensive and protected from endotoxin-induced hypotension. FASEB 21:1689-1698

47. Pesquero JB, Araujo RC, Heppenstall PA, Stucky CL, Silva JA Jr, Walther T, Oliveira SM, Pesquero JL, Paiva AC, Calixto JB, Lewin GR, Bader M 2000 Hypoalgesia and altered inflammatory responses in mice lacking kinin B1 receptors. Proc Natl Acad Sci USA 97:8140-8145

48. el-Dahr SS, Yosipiv IV, Lewis L, Mitchell KD 1995 Role of bradykinin B2 receptor in the developmental changes of renal hemodynamics in the neonatal rat. Am J Physiol 269:F786-F792

49. Cervenka L, Harrison-Bernard LM, Dipp S, Primrose G, Imig JD, El-Dahr SS 1999 Early onset salt-sensitive hypertension in bradykinin $\mathrm{B}(2)$ receptor null mice. Hypertension 34:176-180

50. Fan H, Harrell JR, Dipp S, Saifudeen Z, El-Dahr SS 2005 A novel pathological role of p53 in kidney development revealed by gene-environment interactions. Am J Physiol Renal Physiol 288:F98-F107

51. Jouret F, Igarashi T, Gofflot F, Wilson PD, Karet FE, Thakker RV, Devuyst O 2004 Comparative ontogeny, processing, and segmental distribution of the renal chloride channel, ClC-5. Kidney Int 65:198-208

52. Matus CE, Ehrenfeld P, Pavicic F, Sarmiento JM, Astroza A, Sanchez T, Salem C Concha M, Vidal MA, Gonzalez CB, Figueroa CD 2008 Activation of kinin B receptor triggers differentiation of cultured human keratinocytes. $\mathrm{Br} \mathrm{J}$ Dermatol 159:792-803 